Finanse, Rynki Finansowe, Ubezpieczenia nr 5/2017 (89), cz. 1

\title{
Growth of exports as a precondition for reindustrialisation of the Polish economy
}

\author{
Maria Sierpińska, Małgorzata Kowalik*
}

\begin{abstract}
The paper focuses on issues related to foreign trade equilibrium and defines directions of industrial development that could boost Poland's exports.

Data showing the wider industry's role in generating gross value added as well as exports and imports have been sourced from statistics published by Poland's Central Statistical Office (GUS). The authors calculated the growth in exports and imports to determine the trend in foreign trade and Poland's balance of trade.

Between its accession of to the European Union and 2014, Poland's balance of trade was persistently adverse. The deficit in foreign trade deteriorated in the first years of the economic crisis. Because of its excessive indebtedness and the need to service foreign debt Poland must intensify its exports. A favourable balance of trade can be achieved through the development of knowledge-based industries rather than through the hitherto reliance on cheap labour. Reindustrialisation of the Polish economy must take into account EU's energy and climate policies and as well as its environmental regulations. These regulations demonstrate the need for environmental projects to reduce energy consumption and the use of environmental resources in a bid to preserve them for future generations.
\end{abstract}

Keywords: exports/imports of Poland, reindustrialisation of the Polish economy

\section{Introduction}

The transformation of the Polish economy after 1989 has largely undermined Poland's industrial base. The underlying processes were particularly evident in the 1990s. According to a Polish Industrial Lobby report, at least one third of the industrial potential has disappeared. The losses are too severe to be reversed by a mere inter play of market forces. Indeed, market mechanisms support stronger economies and eliminate weaker ones (Horodecki, Potrzebowski et al., 2012).The Polish economy is one of the weakest in the European Union, a fact that is further corroborated by its indebtedness and foreign trade deficits.

Undoubtedly, deindustrialisation processes have also occurred in highly developed countries. However, despite the rise in unemployment and the decline in the number of well-paid industrial jobs, post-industrial countries have not sustained a decline in their living standards. This is because the vast majority of goods are produced in the "factories of the world". Deindustrialisation in the USA and Europe corresponds to the industrialisation

\footnotetext{
* Professor Maria Sierpińska, University of Science and Management in Warsaw, ul. Pawia 55, 01-030 Warszawa, email: msierpinska@o2.pl; Małgorzata Kowalik Ph.D., Cracow University of Economics, Department of Economics and Enterprise Organisation, ul. Rakowicka 27,31-510 Kraków, e-mail: kowalikm@uek.krakow.pl.
} 
of China, India, Vietnam, Malaysia and other Asian countries. This creates a new global division of labour. "If these goods were produced in countries with post-industrial economies", writes Hrynkiewicz (2011, p. 25), "it would obviously be impossible to maintain the relatively low prices for goods because of labour costs."

The condition of the industry strongly affects economic growth and job creation. The recent crisis has shown that the more industrialised EU countries suffered less from the effects of the economic downturn. It entails that Poland needs to develop modern industries and to strengthen the share of domestic capital in them. This will contribute to internationalisation of enterprises and growth in exports, thus improving Poland's balance of trade.

The paper aims to show the pace of export and import growth and the level of foreign trade balance as determinant sunder lying the rate and directions of reindustrialisation of the Polish economy. Actually, an increase in exports accelerates corporate growth, mitigates risksto businesses and helps them to steer clear of the middle-income trap. Additionally, export also forces companies to increase product competitiveness and brings with it economies of scale.

\section{Industry's role in generating GDP}

Industry's role in a country's economic development is evidenced by its contribution to gross value added (GVA) (Table 1). In 1995, the wider industry's share in Poland's GBP amounted to nearly $28 \%$. After the liquidation of many companies which found themselves unable to cope with rising competition from imported products, the rate dropped to $23.3 \%$ in 2000. After Poland's accession to the European Union, highly developed countries moved their factories to Poland due to low labour costs and high quality of production. This led to an increase of industry share in gross value added to $26.1 \%$ in 2015 . The EU average for the year was $19 \%$.

Compared to 1995, in 2015 several countries witnessed an increase in their industry's GVA. In Ireland, this share increased from $25.6 \%$ in 1995 to $39.1 \%$ in 2015 , i.e. by 13.6 p.p. Several EU countries first experienced a decline in industry's contribution to the creation of gross value added only to see it increase in recent years. This trend has been manifest in France, Italy, Denmark, Finland, Slovenia and Croatia. These countries have begun to rebuild their industrial base. In other European countries, the downward trend persisted throughout the period of the study. The biggest drop was reported in the UK (11.2 p.p.), Latvia (10 p.p.), Italy (7 p.p.), Finland (7.4 p.p.) and Belgium (6.7 p.p.). The wider industry in Bulgaria, Germany, Austria and Denmark made a relatively stable contribution to these countries' GVA. 
Table 1

Gross Domestic Product by Industry in selected countries in 1995-2015

\begin{tabular}{|c|c|c|c|c|c|}
\hline Country & 1995 & 2000 & 2005 & 2012 & 2015 \\
\hline Ireland & 25.6 & 28.0 & 22.2 & 26.3 & 39.1 \\
\hline Netherlands & 21.6 & 19.1 & 18.6 & 19.4 & 15.4 \\
\hline Belgium & 23.1 & 21.9 & 19.3 & 16.5 & 16.3 \\
\hline France & 19.0 & 17.8 & 15.4 & 12.5 & 14.1 \\
\hline Portugal & 21.8 & 29.3 & 18.0 & 18.5 & 17.3 \\
\hline Spain & - & 20.8 & 18.2 & 17.4 & 17.0 \\
\hline UK & 24.5 & 20.8 & 16.7 & 14.6 & 13.3 \\
\hline Austria & 23.6 & 23.7 & 23.0 & 21.8 & 21.9 \\
\hline Italy & 24.3 & 22.6 & 20.3 & 18.3 & 18.8 \\
\hline Denmark & 20.2 & 21.1 & 20.0 & 16.7 & 18.7 \\
\hline Germany & 25.4 & 25.2 & 25.2 & 25.8 & 25.9 \\
\hline Sweden & 25.5 & 24.2 & 23.2 & 20.3 & 20.1 \\
\hline Finland & 28.0 & 28.0 & 25.3 & 19.0 & 20.6 \\
\hline Poland & 27.9 & 23.3 & 24.6 & 24.8 & 26.1 \\
\hline Slovenia & 28.7 & 28.1 & 27.1 & 25.2 & 27.3 \\
\hline Croatia & 26.0 & 24.2 & 21.3 & 20.8 & 21.2 \\
\hline Greece & - & 14.0 & 12.7 & 14.3 & 12.6 \\
\hline Cyprus & 13.9 & 12.2 & 11.1 & 9.2 & 7.9 \\
\hline Estonia & 25.4 & 21.6 & 21.2 & 22.3 & 21.2 \\
\hline Latvia & 26.4 & 18.6 & 16.2 & 19.5 & 16.4 \\
\hline Lithuania & 24.3 & 23.7 & 24.9 & 24.9 & 22.6 \\
\hline Czech Republic & 30.8 & 30.9 & 31.3 & 31.2 & 32.1 \\
\hline Slovakia & 31.1 & 28.8 & 29.4 & 27.8 & 25.2 \\
\hline Hungary & 25.4 & 27.1 & 26.1 & 27.3 & 27.4 \\
\hline Romania & - & 27.7 & 28.1 & 32.5 & 26.4 \\
\hline Bulgaria & 23.4 & 21.2 & 23.0 & 24.5 & 23.0 \\
\hline
\end{tabular}

Source: Eurostat http://ec.europa.eu/eurostat/statistics-explained/images/5/5d/Gross_value_added_at_basic prices\%2C_2005_and_2015_\%28\%25_share_of_total_gross_value_added\%29_YB16.png (15.11.2016).

The past few years has been marked by an ingrained belief that the best economy is a service-based one. However, Europe's more industrialised economies fared relatively better off in times of the crisis compared to less industrialised countries and those with an expanded banking sector. In 2013, the unemployment rate in Germany decreased by $28 \%$ on 2008 , and that at a time of an economic crisis (Czapiński, Sierpińska-Sawicz, 2014, p. 70). It seems that the importance of industry both in Poland and in the European Union will grow. The number of manufacturing jobs will increase. Given the quality of human capital, it can be assumed that industry has a good chance of growth in Poland. 


\section{The Import-export relation as a premise of industrial development}

The period between 2004 and 2015 saw a definite strengthening of Poland's position in the global economy, including through the country's participation in international trade. In 2015, the ratio of exports of goods and services to GDP stood at 50\% compared to $33.1 \%$ in 2003, the year before Poland's accession to the EU. However, Table 2 also shows that industry still continues to be underdeveloped in Poland and is unable to achieve a balance of trade, not to mention a surplus. In 2015, exports were more than 3 times higher than in 2004, the yearof Poland's accession to the European Union. Imports increased almost 2.5 times over that time. The annual growth rate of these economic indicators varied widely. In 2005, exports increased by $20.7 \%$ and imports by $13.7 \%$. In 2007 , exports increased by $12.8 \%$ and imports by $19.4 \%$ on 2006 . Likewise, in 2014 exports increased by $5.7 \%$ and imports by $7.3 \%$. The trend was only reversed in 2015 when Poland reported a surplus of exports over imports amounting to 3.7 billion euros, the first such development since the EU accession. One of the reasons was a weakening of the Polish currency later in the year. In 2007, at the beginning of the global economic crisis, the negative trade balance amounted to 22.4 billion euros, i.e. over 100 billion zlotys. In 2008, the foreign trade deficit increased to almost 30 billion euros, or over 120 billion zlotys. In 2011, imports outstripped exports by over 20 billion euros. At a time of the economic crisis, developed countries tapped into the Polish market in a bid to retain their production and jobs levels, all at a loss to the Polish economy. Strengthened by an inflow of EU funds, the Polish zloty boosted the attractiveness of imports and consequently deepened the country's foreign trade deficit. Yet only when exports grow faster than imports will there be a favourable impact of foreign trade on GDP growth.

Table 2

Change in exports and imports and foreign trade balance in Poland in 2004-2015

\begin{tabular}{|c|c|c|c|c|c|c|c|}
\hline Year & $\begin{array}{l}\text { Value of } \\
\text { exports } \\
\text { (euro bn) }\end{array}$ & $\begin{array}{l}\text { Change, \% } \\
\text { (previous year } \\
=100 \text { ) }\end{array}$ & $\begin{array}{l}\text { Change, } \% \\
2004=100\end{array}$ & $\begin{array}{l}\text { Value } \\
\text { of imports } \\
\text { (euro bn) }\end{array}$ & $\begin{array}{l}\text { Change, \% } \\
\text { (previous } \\
\text { year }=100 \text { ) }\end{array}$ & $\begin{array}{l}\text { Change, } \% \\
2004=100\end{array}$ & $\begin{array}{l}\text { Differential be- } \\
\text { tween imports } \\
\text { and exports } \\
\text { in euro bn }\end{array}$ \\
\hline 2004 & 58.5 & 100.0 & 100.0 & 71.4 & 100.0 & 100.0 & -12.9 \\
\hline 2005 & 70.6 & 120.7 & 120.7 & 81.2 & 113.7 & 113.7 & -10.6 \\
\hline 2006 & 87.0 & 123.2 & 148.7 & 100.8 & 124.1 & 141.2 & -13.8 \\
\hline 2007 & 98.1 & 112.8 & 167.7 & 120.4 & 119.4 & 168.6 & -22.3 \\
\hline 2008 & 112.7 & 114.9 & 192.6 & 142.4 & 118.3 & 199.4 & -29.7 \\
\hline 2009 & 95.3 & 84.6 & 162.9 & 107.5 & 75.5 & 150.6 & -12.2 \\
\hline 2010 & 117.9 & 123.7 & 201.5 & 134.2 & 124.8 & 188.0 & -16.3 \\
\hline 2011 & 132.3 & 112.2 & 226.1 & 152.6 & 113.7 & 213.7 & -20.3 \\
\hline 2012 & 140.8 & 106.4 & 240.7 & 154.0 & 100.9 & 215.7 & -13.2 \\
\hline 2013 & 148.9 & 105.8 & 254.5 & 157.0 & 101.9 & 219.9 & -8.1 \\
\hline 2014 & 157.4 & 105.7 & 269.1 & 168.4 & 107.3 & 235.9 & -11.0 \\
\hline 2015 & 178.7 & 113.5 & 305.5 & 175.0 & 103.9 & 245.1 & +3.7 \\
\hline
\end{tabular}

Source: authors' own calculations based on NBP data, GUS (15.11.2016). 
It should be noted that the relatively faster growth of exports than imports was mainly due to low labour costs. This led to a high share of medium and low tech exports, while the share of high tech products amounted to $8.5 \%$. In terms of the share of technologically advanced products in total exports, Poland fares much worse not only than the highly developed countries but also under perform sother post-communist countries (France 21.6\%, Great Britain 16.7\%, Czech Republic 15.4\%, Hungary 15.2\% Germany 14 , 8\%, Slovakia 9.8\%, EU average 17.0\%) (Strategia na rzecz..., p. 106).

Poland's manufactures end up mainly in the European Union (80\%). In 2015, Poland sent $27.1 \%$ of its exports to Germany, $6.7 \%$ to the UK, $6.7 \%$ to the Czech Republic, $5.5 \%$ to France and $4.8 \%$ to Italy. There vival of Polish exports will depend not only on the demand in the Euro zone but also on the situation of the Chinese economy and another Asian countries. Their situation affects the value of exports by Polish subcontractors' supplying multinational corporations. Poor economic performance in countries importing final products from developed countries will weaken the pace of economic development in Poland. As a subcontractor, Poland does not compete on the foreign markets for final products. This points to the need for reindustrialisation and production of manufactures by the Polish industry that both meet the domestic market demand and provide export revenue at least covering the volume of imports and providing funds for servicing external debt.

\section{Tools for boosting exports}

The need to increase export dynamics has several underlying reasons. The most important of these are undoubtedly the projected reduction in EU funds in the next financial perspective after 2020 and the growing liberalisation of global trade. This trend is reflected not only in measures promoted by the WTO, but also in regional trade agreements including CETA. Liberalisation of trade and strong growth of economic patriotism in some countries (France, Germany) can marginalise Poland's position in the global economy. In order to prevent this, the participation of Polish companies in the international economic exchange must increase. This precondition can be met if production based on raw materials and cheap labour is reduced in favour of high-skilled labour force and knowledge-based production.

Highly developed countries (Germany, France, and USA) use a number of instruments to stimulate their exports. Emulating their mode of operations, three groups of instruments could be used to accelerate exports: institutional, organisational and financial.

The basic tool used to support companies' exports, promotion of Polish products and encouragement of foreign investors to invest in Poland should involve economic diplomacy, mainly to promote economic and international economic cooperation. The role of economic diplomacy is to monitor and inform about economic and development policies in the host country and to advise on how to effectively influence them. Economic diplomacy refers to the economy on a macroeconomic scale, but at the same time affects the success of individual companies in the foreign market (Molendowski, 2007, p. 41). Business diplomacy aimed 
at facilitating international exchange of goods and services, intensifying trade or promoting the national economy as a brand also facilitates the foreign expansion of domestic businesses. Improving the perception of a given economy, these activities indirectly facilitate companies' entry into foreign markets. On the other hand, the main objective of trade diplomats is to "open up foreign markets for domestic companies, support the domestic business and financial sectors in their pursuit of economic success and, through these, the success of the entire economy. Trade diplomats provide information on opportunities available to exporters or on investment in the host country (Halik, 2014, p. 75). They serve directly the company or the industry.

A similar role could be played by the economic self-government of companies operating in Poland. A well-functioning self-government could influence the shape of the country's foreign economic policy.

A number of organisational tools can speed up growth of exports. Undoubtedly, these tools involve economic missions accompanying political visits, conferences on export promotion and export markets. Such solutions serve to increase small and medium enterprises' interest in foreign markets. The same role can be played by involving Polish companies in the international market for the most innovative and advanced technologies.

Access to accurate information on products or foreign markets to which Polish companies would like to export their products is an important tool for acquiring new markets. This is especially important for small and medium-sized enterprises. The funds from PARP allocated to support small and medium-sized companies should therefore be used to directly finance intelligence gathering and provision rather than given to companies. It would eliminate the need to verify if the funding has been used appropriately, which, in turn, would reduce bureaucracy and its costs and consequently also make companies' functioning more flexible. Free access to basic information is provided by the Ministry of Development in cooperation with economic departments of Polish embassies. Information on foreign markets focuses on the economic situation of the country, its legal environment, and announcements on foreign trade fairs, economic missions or various types of conferences on foreign trade.

Financial support is provided by the Bank Gospodarstwa Krajowego (BGK) and the Export Credit Insurance Corporation (KUKE). BGK acts as a state-owned development bank and often takes the risk of financing entities that do not receive commercial bank support. It also declares its readiness to take up shares in foreign subsidiaries of Polish companies. 2015 saw the establishment of the BGK International Expansion Fund aiming to finance export financing. In addition, a number of commercial banks offer export financing instruments such as letters of credit, L/C discount, factoring of foreign receivables, export credits, currency risk mitigation. Export can also be boosted by the use of surety and guarantee funds.

KUKE's product offering which insures export credits is mainly accessed by companies operating in markets with an increased risk of counterparty insolvency. The problem of counterparty insolvency is particularly acute in Eastern Europe and Asia. Insurance of 
contracts with foreign counterparties is used by new entrants to the export market and multiannual exporters alike. The risk of not being paid by foreign contractors is also mitigated by the use of international factoring.

In addition to KUKE and BGK, support for exporters is also provided by the likes of the Polish Information and Foreign Investment Agency, the Polish Chamber of Commerce and the Polish Agency for Enterprise Development. These first two institutions mainly provide information on markets and foreign counterparties.

One of the tools for promotion of export is funding by the Polish Agency for Enterprise Development granted to companies seeking advice on the development of a business model related to the internationalisation of business activities. The grant is intended, e.g.to finance analysis of export potential, assessment of the potential for making a sale, selection of the most effective marketing tools and search for available sources of external financing of export activities reducing risk. Funding is also available for advisory services related to customisation of products to meet the needs of target markets, co-financing of participation in foreign fairs and exhibitions or participation in trade missions.

\section{The impact of industrial development on growth of exports}

The importance of the wider industry for the European Union has already been underscored in the Lisbon Strategy. The concrete directions for its fostering are factored into an industrial policy for the globalisation era, one of the seven flagship initiatives under the Europe 2020 Strategy. The Europe 2020 strategy aims to achieve growth that is: intelligent - thanks to more effective investment in education, research and innovation; balanced - thanks to a strong shift towards a low-emissions economy, and socially inclusive with particular emphasis on job creation and poverty reduction. The strategy focuses on five far-reaching goals in the areas of employment, innovation, education, poverty reduction and climate and energy. The re-industrialisation program emphasises in particular that green growth is needed. The EU has indicated six areas that it considers as priorities (Europe 2020):

- clean production technologies,

- sustainable construction,

- low emission vehicles,

- intelligent power grids,

- products of biological origin,

- key technologies (e.g. nanotechnologies).

The implementation of this program will be hampered by climate policies and the need to reduce greenhouse gases, high energy and gas prices.

Poland's industries, like those in other European countries, face major challenges. It is necessary to stimulate economic growth needed to create new jobs and prosperity for citizens as well as to reduce Poland's debt burden. 
The industry must have adequate international links that will serve to create global channels for the distribution of goods. In order to compete effectively on the international market, Polish companies must implement new production technologies and increase the production of goods of a higher added value. It is therefore necessary to move away from primary products to technologically advanced ones.

According to Shomburg and Wandalowski (2015, p. A11), the implementation of innovative technological or product solutions is contingent upon the simultaneous activation of four growth factors, the main one being high-margin exports. Expansion into foreign markets should involve the most advanced products and services targeted to many markets in order to achieve economies of scale. In order for national export champions to build a competitive advantage it is imperative to ensure the cooperation of suppliers providing components, universities offering their scientific potential and the state creating business-friendly legislation and enforcing it. Exporters should help cooperating companies and institutions to make their presence in foreign markets, as is done in the name of economic patriotism by companies from highly developed countries.

The growth in exports of technologically advanced secondary products is also conditional upon attracting foreign investment in ever more technologically advanced products. Only such companies should be admitted to special economic zones and periodically exempted from income tax rather than companies carrying out simple labour-intensive production and using cheap labour, which is a current trend. Entry into the markets of highly developed countries can also be achieved through acquisitions and mergers by Polish owned companies. Another undeniable precondition for growth of exports involves the creation of start-ups capable of succeeding in the global market. For example, within the framework of the "Nation" Start-up Project, Israel gained a record share of high-tech exports in its overall exports. In recent years, the share has exceeded $40 \%$ of all Israeli exports (Karpiński, 2012, p. 135). Start-ups develop in stages. At the initial stages of development, funding through national venture capital should be ensured, which will guarantee the acquisition of these companies by domestic capital. Otherwise, small companies with innovative solutions will be absorbed by foreign capital groups. Preference for the development of the mainly Polish domestic processing industry is justified because only the domination of domestic ownership in an industry ensures the sustainability of its development.

As a member of the European Union, Poland's involvement in the program of the reindustrialisation of the economy must take into account the provisions of policies on energy, climate and $\mathrm{CO}_{2}$ emissions as well as other regulations. Bearing these determinants in mind, transformation should occur in energy-efficient, low-carbon, resource-efficient industries. One industry's production waste should be the raw material in another value chain. This will not only cut production costs, but will also reduce environmental pressures and ensure a more equitable distribution of environmental resources between generations.

Considering the above, the Responsible Development Strategy envisages the development of such sectors as transport, electromobility, advanced medicine and biotechnology, 
food, military systems, aerospace and shipping and ecobuildings. In particular, the following strategies should be mentioned:

- technology development, design and construction of Polish vessels and marine constructions, production of specialised vessels of high added value,

- design and production of Polish electric vehicles for urban transport (electric buses, trams), Polish electric passenger cars,

- development of technology and production of Polish rail vehicles with special emphasis on passenger transport vehicles,

- strengthening competitiveness on the European IT services market,

- development of modern medical services and products using innovative communication technologies and improved access to specialised medical services,

- production of advanced generic drugs and biosimilars,

- production of medical devices and Polish medical robot, artificial organs, software solutions and systems of support or substitution of senses,

- preparation and implementation of ecological building products satisfying requirements for energy efficiency and modern building materials,

- production of Polish furniture - development of industrial design and creation of strong Polish brands using modern technologies and eco-design,

- strengthening the position of the Polish industry in the global mining and construction machinery market.

The development of these products and services requires the co-operation of a number of private and public entities. The activities of the state should, in turn, focus on the creation of legal, organisational and investment incentive systems for project development and implementation. In order to implement the projects, the government intends to set up task teams and leaders - project managers responsible for coordinating the implementation of these projects from research through commercialisation, production to entry into international markets.

\section{Conclusions}

Throughout the transformation of the Polish economy, development has been based mainly on importation of technology and subcontracting for global companies. Using a relatively cheap and well-educated work force, these companies produce labour-intensive and technologically sophisticated products in Poland or assemble their products in their Polish subsidiaries. They have so far competed on cost, but under conditions of rising costs, especially labour costs, they can shift their production capacities to cheaper labour markets, which will deprive the Polish economy of jobs. This necessitates the need to reindustrialise and develop knowledge-intensive industries. The changes must be gradual though. Indeed, it is impossible to depart within a short timeframe from subcontracting, but such subcontracting 
must become increasingly knowledge-intensive, generating higher added value and providing employees with higher salaries.

The underdevelopment of the Polish industry, especially of high tech industries accompanied by excessive dependence of our economy on foreign ownership of capital reduces the competitiveness of the Polish economy. At the same time, today's global competitive struggle is about eliminating competitors for scarce natural resources. Polish companies, too weak in terms of their capital resources, are unable to beat off this competition. Polish industries must therefore be based on knowledge rather than on raw materials.

Industry development should become a force that stimulates the socio-economic development of the country, balancing trade with foreign countries and stabilising the labour market. In the context of the financial and economic crisis, it turned out that industrial jobs are more sustainable than jobs in services and subcontracting. Reindustrialisation of the economy should therefore move towards a balanced and sustainable industrial policy that maintains and modernises existing industrial potential, develops high-tech products and opens new markets.

\section{References}

Czapiński, J., Sierpińska-Sawicz, A. (2014). Poziom bezrobocia w Polsce i jego skutki dla przedsiębiorstw. Ekonomika i Organizacja Przedsiębiorstw, 11 .

Europa 2020 - strategia na rzecz inteligentnego i zrównoważonego rozwoju sprzyjającego włączeniu społecznemu (2010). Retrieved from: http://ec.europa.eu/europe2020/europe-2020-in-a-nutshell/priorities/index_pl.htm\#top (24.03. 2017).

Halik, J. (2014). Działania polskiej dyplomacji gospodarczej wspierające internacjonalizację przedsiębiorstw. Ekonomika i Organizacja Przedsiębiorstw, 2.

Horodecki, J., Potrzebowski, H., Soroka, P. (2012). Raport o przemyśle, Warszawa: Oficyna Wydawniczo-Poligraficzna SIM. Retrieved from: http://www2.plp.info.pl/wp-content/uploads/2012/12/Raport-o-przemysle.pdf (28.10.2015).

Hrynkiewicz, J.T. (2011). Schyłek społeczeństwa przemysłowego jako źródło niepewności. Przegląd Organizacji, 6.

Karpiński, A. (2012). O polska strategie przemysłowa (wzorce uniwersalne czy specyfika przemystu). Warszawa: Oficyna Wydawnicza Warszawskiej Szkoły Zarządzania.

Molendowski, E., Polan, W. (2007). Dyplomacja gospodarcza: rola i znaczenie w polityce zagranicznej państwa. Kraków : Oficyna Wydawnicza Wolters Kluwer bussines.

Strategia na rzecz Odpowiedzialnego Rozwoju. Retrieved from: http://www.money.pl/gospodarka/wiadomosci/artykul/projekty-strategi-na-rzecz-odpowiedzialnego,143,0,2269583.html (23.03.2017).

Szomburg, J., Wandałowski, M. (2015). Cztery silniki rozwoju. Rzeczpospolita, 22 December.

www.trade.gov.pl. 


\section{ROZWÓJ EKSPORTU JAKO WARUNEK REINDUSTRIALIZACJI GOSPODARKI POLSKIEJ}

Streszczenie: W artykule zawarte zostały problemy dotyczące równowagi w handlu zagranicznym oraz określono kierunki rozwoju przemysłu, które mogłyby zdynamizować eksport.

Dane do pokazania roli przemysłu w generowaniu wartości dodanej brutto PKB oraz eksportu i importu pozyskane zostały ze statystyki GUS. Obliczono dynamikę eksportu i importu w celu ustalenia trendu rozwoju handlu zagranicznego oraz saldo obrotów zagranicznych.

Od przystąpienia Polski do Unii Europejskiej saldo handlu zagranicznego aż do 2014 roku było ujemne. Deficyt w handlu zagranicznym pogłębił się w pierwszych latach kryzysu gospodarczego. W związku z nadmiernym zadłużeniem Polski i potrzebą obsługi zadłużenia zagranicznego powstaje konieczność zdynamizowania eksportu. Uzyskanie dodatniego salda w handlu zagranicznym możliwe jest poprzez rozwój przemysłów opartych na wiedzy nie zaś taniej sile roboczej jak dotychczas. Reindustrializacja gospodarki polskiej musi uwzględniać unijną politykę energetyczną, klimatyczną i unijne regulacje środowiskowe. Regulacje te narzucają konieczność realizacji przedsięwzięć proekologicznych ograniczających zużycie energii i zasobów środowiska w celu zachowania ich dla przyszłych pokoleń.

Slowa kluczowe: export/import Polski, reindustrializacja polskiej gospodarki

\section{Citation}

Sierpińska, M., Kowalik, M. (2017). Growth of exports as a precondition for reindustrialisation of the Polish economy. Finanse, Rynki Finansowe, Ubezpieczenia, 5 (89/1), 377-387. DOI: 10.18276/frfu.2017.89/1-31. 